\title{
Market Concentration and its Impact on Liner Shipping in Ghana
}

\author{
Mary Bossman and Qu Yaping
}

\section{ABSTRACT}

Ever since the introduction of ocean liner shipping in the maritime trade industry, there has been a great and positive impact on the maritime industry in terms of trade. Liner shipping lines enjoy degrees of antitrust immunity in various parts of the world. With about 400 liner shipping lines presently and still counting the industry experiences very high concentration in the market. Few of the liner shipping lines occupy a maximum portion of the industry's market shares whereas the remaining occupy very less or insignificant market shares. In order to survive the oligopolistic nature and concentration of the market, firms seek to cooperative agreements where they are able to share assets and in some cases go as far as merging. Mergers and acquisitions involve the risk of high cost of investment therefore it is not always the option for the relative smaller firms as a means of increasing market shares, but this cannot be said for the larger firms. Consortia, and global strategic alliances do not require such investment. These cooperative agreements rather help member firms to utilize assets and enjoy economies of scale and as a result increase firm growth. Liner shipping lines also as a means of increasing market shares, decrease freight rates and offer value added services to their customers.

Keywords: Liner Shipping, Market Concentration, Market Shares, Mergers.
Submitted : July 06, 2021

Published : August 15, 2021

ISSN: 2507-1076

DOI: $10.24018 /$ ejbmr.2021.6.4.975

\section{Mary Bossman}

Jiangsu University, School of Management, China.

(e-mail: bossmanmary10@yahoo.com) Qu Yaping*

Jiangsu University, School of Management, China.

(e-mail: yapingqu0319@gmail.com)

*Corresponding Author

\section{INTRODUCTION}

"The dynamic stability of supplier market shares within concentrated industries may provide an alternate means of 'gauging firms' responses to changes in structural characteristics and/or changes in regulatory policy" [1]. In the liner shipping industry relative larger firms have exorbitant market shares whereas the relative smaller ones have very less or insignificant market shares [2]. 'Negatively' affected firms' (relative smaller firms with lesser market shares) have to seek to certain means to remain in competition or otherwise have to exit the market. "On one hand, market power is a central element of most competition rules throughout the world, and market definition is the most widely used method of assessing market power, taken by some to be mandatory in certain things" [3]. There is a relationship between a country's export market shares and its competitiveness because rising market shares reveal a strong performance of a country's producers in international markets and vice versa [2]. According to [4] market share stability has an impact on how firms compete in the market.

Maritime transport is a core element in international logistics, contributing around 80 per cent of the volume of global trade [5]. "Shipping is a global service industry that by general acknowledgement provides the lifeline of international trade" [6], [7]. There are three modes of operation in the maritime transportation namely, liner shipping, tramp shipping and the industrial shipping. "In industrial shipping the cargo owner also owns the ship" [8]. Liner ships operate according to schedules. In liner shipping there are published fixed ports with dates of calls. The opposite happens in tramp shipping. In liner shipping published or advertised dates of ports calls are followed to the latter except in situations where certain circumstances are not favorable at the ports of call. In liner shipping even when a vessel is not full to capacity, it is still expected to make its scheduled voyage or risk losing customers that expect the carrier to adhere to its schedules. "Liner operating companies generally transport high-value consumer and intermediate goods, including all seaborne containerized cargo, automobiles, and other machinery" [9]. Liner industry has a profound effect on its consumers and exporters as a result of the variety of goods transported [10]. Liner shipping is the most efficient mode of transportation of goods and its relevance cannot be over emphasized. Liner container operators often use very large vessels. "In one year, a single large containership could carry over 200,000 container loads of cargo" [11], [32]. "It would require hundreds of freight aircraft, many miles of rail cars, and fleets of trucks to carry the goods that can fit on one large liner ship" [12].

Decisions regarding pricing and capacity level of liner shipping firms determine their performance. Depending on the market share, liner shipping lines decide the number of vessels to order for instance the top three have more than 140 
vessels on order followed by COSCO and Hanjin with 43 and 24 vessels respectively [13], [21]. Market shares of liner shipping companies have been derived from capacity share by many researchers and major industry reports. The Aphaliner is a typical example. In most cases Firms with greater market share have the tendency of controlling the market. Faced with Liner Concentration where relatively larger liner shipping companies increase their market shares at the expense of the remaining smaller companies [10], [14]. There have been major structural changes in the international liner shipping industry caused by a number of factors and liner companies have responded to these challenges by engaging in merges, acquisitions and global strategic alliances [6], [15]. "The market power argument provides a possible theoretical explanation for the formation of strategic alliances in liner shipping" [16], [21]. Literature describes the market structure of global liner shipping industry as an oligopoly. The cause of this is that Liner markets are "inherently unstable" [16] prompting a lot of mergers and acquisitions to keep the business going. Ghana's maritime industry seems to be deviating from the global trend of acquisitions and mergers but rather continues to see an increase in the number of shipping lines and agents. Knowledge of their market shares and market concentration would provide an invaluable tool for professionals within the industry to forego the negative effects that unanticipated changes can have on the various firms.

\section{A. Liner Shipping}

\section{LITERATURE REVIEW}

Liner vessels transport goods in very high-capacity by using regular routes on fixed schedules. There are about 400 liner services in operation in present day [17], [33]. Liner shipping trade transport work-in-progress goods as well as finished cargo. Most liner ships are containerships and others are a combination of container and RoRo. "Shipping is a global service industry that by general acknowledgement provides the lifeline of international trade" [8], [18] There are three modes of operation in the maritime transportation namely, liner shipping, tramp shipping and the industrial shipping. "In industrial shipping the cargo owner also owns the ship" [19]. Liner ships operate according to schedules. In liner shipping there are published fixed ports with dates of calls. The opposite happens in tramp shipping. In liner shipping published or advertised dates of ports calls are followed to the latter except in situations where certain circumstances are not favorable at the ports of call. In liner shipping even when a vessel is not full to capacity, it is still expected to make its scheduled voyage or risk losing customers that expect the carrier to adhere to its schedules. "Liner operating companies generally transport high value consumer and intermediate goods, including all seaborne containerized cargo, automobiles, and other machinery" [20]. Liner industry has a profound effect on its consumers and exporters as a result of the variety of goods transported [20]

\section{B. Market Shares in Liner Shipping}

Market share stability has an impact on how firms compete in the market [5] and [12] agree that the bigger the market share of a firm; the more profit they gain. However, it is not always so [12], [17]. Very high market share owning firms attract antitrust suits by other firms owning lesser shares. But since liner shipping lines are granted varying degrees of antitrust immunity under the auspices of the Shipping Act of 1916, the 1961 Amendments, and the Shipping Act of 1984 [3] liner shipping firms with very high market shares can go on to 'enjoy' their profit. According to [4] concentration, market growth, and entry destabilize shares while market size, exit, and demand shocks are stabilizing factors.

\section{Liner Concentration}

The major shipping lines in the liner shipping industry keep expanding regardless the high concentration level. "Understanding the growth of major shipping companies and its impact on the market concentration is important for public agencies to prevent potential inefficiencies associated with greater market concentration by identifying the firms whose further growth can increase the concentration level and stipulating appropriate policies" [10]. A study by [16] shows a relationship between firm growth, market share and market concentration and concludes that liner concentration is as a result of firm growth of major liner firms in liner shipping. When there is liner concentration the larger firms do not need to partake in alliances, conferences or consortia to operate. They are usually independent of other firms. Maersk line certainly provided an excellent example of this when they resigned from the Grand Alliance immediately after acquiring P\&ONL [21]. However, liner concentration leaves the smaller carriers no other option but to seek alliances in order to survive against large carriers [22]. Four-firm Concentration Ratio is one of other means of measuring liner concentration. The Four-firm concentration ratio is given as:

$$
C 4=\frac{S 1+S 2+S 3+S 4}{\mathrm{ST}}=\mathrm{W} 1+\mathrm{W} 2+\mathrm{W} 3+\mathrm{W} 4
$$

S: sales of individual firms; W: market shares.

$\mathrm{T}$ : Interpretation of Ratio.

\begin{tabular}{|c|c|c|}
\hline \multicolumn{3}{|c|}{ TABLE I: INTERPRETATION } \\
\hline & $\begin{array}{c}\text { Liner } \\
\text { Concentration }\end{array}$ & Market Structure \\
\hline $0 \%$ & No concentration & Perfect Competition \\
\hline $1-50 \%$ & Low Concentration & Monopolistic Competition \\
\hline $51-80 \%$ & $\begin{array}{c}\text { Medium } \\
\text { Concentration }\end{array}$ & Monopolistic/Oligopoly \\
\hline $81-100 \%$ & High Concentration & Oligopoly/Monopoly \\
\hline
\end{tabular}

Some of the larger liner firms go beyond competition against other participating firms in the liner shipping industry by operating certain infrastructure and superstructure at ports in order to control port activities and to operate the port more efficiently and to avoid delays [5], [23].

Liner concentration might even get worse. Studies have revealed that $\mathrm{M} \&$ As can contribute to market concentration [19], [24] and this is a strategy used in the industry by firms to increase their market shares. The trend towards greater concentration is further encouraged by the exorbitant price of new buildings ranging from US\$126 to US\$133 million for vessels in the 9,700 to 10,000 TEU size range and US\$ 6585 million for vessels in the 4,000-5,500 TEU range [25], therefore not encouraging smaller firms. 
TABLE II: TOP 20 LINER SHIPPING LINES WORLDWIDE [1]

\begin{tabular}{cccc}
\hline Rank & Operator & TEU & Share \\
\hline 1 & APM-Maersk & $3,011,970$ & $14.6 \%$ \\
2 & Mediterranean Shipping Co. & $2,657,645$ & $12.9 \%$ \\
3 & CMA CGM Group & $1,799,291$ & $8.7 \%$ \\
4 & COSCO Container Lines & $1,540,770$ & $7.5 \%$ \\
5 & Evergreen Line & 926,998 & $4.5 \%$ \\
6 & Hapag-Lloyd & 924,755 & $4.5 \%$ \\
7 & Hamburg Süd Group & 646,179 & $3.1 \%$ \\
8 & Hanjin Shipping & 620,112 & $3.0 \%$ \\
9 & OOCL & 565,113 & $2.7 \%$ \\
10 & UASC & 564,117 & $2.7 \%$ \\
11 & MOL & 534,807 & $2.6 \%$ \\
12 & APL & 531,805 & $2.6 \%$ \\
13 & Yang Ming Marine Transport & 517,662 & $2.5 \%$ \\
14 & Corp & 497,350 & $2.4 \%$ \\
15 & NYK Line & 400,205 & $1.9 \%$ \\
16 & Hyundai M.M & 383,658 & $1.9 \%$ \\
17 & K Line & 348,820 & $1.7 \%$ \\
18 & Zim & 338,912 & $1.6 \%$ \\
19 & PIL (Pacific Int. Line) & 217,995 & $1.1 \%$ \\
20 & Wan Hai Lines & 137,470 & $0.7 \%$ \\
\hline
\end{tabular}

\section{COOPERATIVE ARRANGEMENTS IN LINER SHIPPING}

Considering the level of concentration in liner shipping market participating firms have no option but to expand aggressively in order to maintain a portion of the market share and keep up with the pace of growth rate of the others. [19], [12], [26]. Liner shipping has adopted cooperative arrangements such as conferences, vessel sharing agreements, strategic/global alliances, capacity stabilization agreements and discussion/talking agreements [20].

\section{A. Conferences}

Conference by [19], [27] is defined as a group of two or more vessel operating carriers which provides international liner services for the carriage of cargo on a particular route or routes within specified geographical limits and which has an agreement or arrangement, whatever its nature, within the framework of which they operate under uniform or common freight rates and any other agreed conditions with respect to the provision of liner services". Liner conferences, also called "shipping conferences" or "ocean shipping conferences", have had the most significant influence on competition in the liner shipping market compared to other organizational forms of operation [8], [28]. The first liner conference was established in 1875 covering routes between the United Kingdom and India, with the aim to control competition among its members [8]. It was the called U.K.Calcutta. Conferences existed before the passing of the U.S antitrust law and their operation in the international arena was practically seen as an extraterritorial phenomenon [13].

After the elimination of conferences in the U.S. and Europe shipping markets, firms in the liner shipping industry were forced into competition [21]. Conferences can be either open or closed. There are open and closed conferences in principle; open conferences as the name implies accept new membership and closed conferences are just the opposite [26]. There are several different views of conferences. Some share the view as anti-competitive cartels, manipulating markets and effective competition in the interest of ship owners [12]. Conferences used fixed quota to avoid competition among member shipping lines [28].

\section{B. Advantages of Conference}

Conferences offer reduced risk to both carriers and shippers in cases of unstable price. Sometimes carriers are exposed to risk of losses, and shippers face uncertainty about freight rates as a result of combination of inelastic supply and demand that leads to a highly unstable price [6]. Creation of stability in the relations between consignors and lines. This guarantees the continuity of services and allow for investments in new tonnage and handling techniques [15]. Offer carriers sufficient control over shipping rates to ensure their continued survival which serves a national security interest [12]. Conferences subsidize smaller less capitalized carriers allowing them to capture network externalities and economies of scale and scope without having to be large or well capitalized themselves [15].

\section{Antitrust Immunity and Conferences}

United States antitrust law is a collection of federal and state government laws that regulate the conduct and organization of business corporations, generally to promote fair competition for the benefit of consumers [11]. Conference agreements have substantial antitrust immunity in many parts of the world (SJOSTROM, 2014). The Shipping Act of 1916 is the oldest surviving U.S. statutory antitrust exemption OECD, 2015. The Shipping Act of 1984 revised the antitrust exemption for carrier agreements. Antitrust immunity under the Shipping Act is, however, constrained by a variety of explicitly prohibited acts and restrictions on "unreasonable practices" [29]. Conferences are granted varying degrees of antitrust immunity under the auspices of the Shipping Act of 1916, the 1961 Amendments, and the Shipping Act of 1984 [27]. The 1916 Shipping Act allowed ocean carriers to enter into price-setting agreements that were immune from antitrust action, but those agreements had to be filed and approved by the U.S. Shipping Board. The 1961 Amendments weakened this antitrust immunity by including a "public interest standard in the approval process for conference agreements conducted by the U.S. Shipping Board' successor, the Federal Maritime Commission [4]. The Shipping Act of 1984, as amended by the Ocean Shipping Reform Act of 1998 (OSRA), provides an alternative competition enforcement regime that includes limited antitrust immunity for ocean common carrier agreements from the antitrust laws [29]. The 1984 Act further authorized service contracts between carriers or conferences and shippers and mandated that members of conference agreements be allow to take independent action on any rate or service item after a notice period of no more than 10 days [6]. One reason that carriers accepted the provisions of the Shipping Act of 1984 was that it actually broadened the antitrust exemption for carrier agreements and streamlined the regulatory process for those carrier agreements [12].

In the United States the Shipping Act of 1984 allows liner companies to establish various sorts of multi-member liner agreements that have limited antitrust immunity, including some that authorize member lines to discuss and voluntarily agree on pricing matters. The 1984 Act shifted the burden of proof so that conference agreements were no longer subject to an approval process, but instead could be contested by the FMC [5]. Agreements automatically became effective after 45 days, the FMC sought an injunction on the basis that the 
agreement was ".... likely, by a reduction in competition, to produce an unreasonable reduction in transportation service or an unreasonable increase in transportation cost" [5]. Conferences have been banned therefore not an option anymore for liner firms.

\section{Ocean Shipping Reform Act (OSRA)}

Ocean Shipping Reform (OSRA) Act was designed to change the way liner shipping operated in US trades; the effort that culminated in the passage of OSRA began in mid1995 with an inter-industry accord on fundamental principles for revising the Shipping Act of 1984 [10]. The OSRA's first commandment is to let the market set the prices, but because of the antitrust immunity arrangement still being applicable the joint setting of prices is still permitted. OSRA permits individual members to negotiate independent confidential service contracts with shippers and prohibits the group from taking any retaliatory action against shippers or carriers that do so [21]. According to Global Insight, (2005) OSRA implements three principles which mitigate the effectiveness of anti-trust exemptions in the liner industry:

1. Freedom of carriers and shippers to negotiate rates, surcharges and terms on an individual and confidential basis

2. Freedom of carriers and shippers to protect contractually the confidentiality of terms and rates, especially rates

3. Freedom of carriers to make operational and capacity agreements with other carriers, as long as that does not confer upon them undue market power.

Consortia and global alliances evolved when conferences were not so attractive because of the limitation of the antitrust laws [17]. "Consortia are operating agreements between liner shipping companies aimed primarily at operating joint services by means of technical, operational or commercial coordination (e.g., joint use of vessels, port installations, marketing organizations, etc.)" [5]. Between the late 1960s and 1970s consortia was established following containerization, and gradually replaced conferences [8]. According to [8] consortia and vessel-sharing agreements have been agreed by shippers as the most suitable form of cooperation among carriers, mainly because of the operational and cost benefits they offer. However, consortia marketed products of all participants collectively with no distinction between products of member lines which made it difficult to differentiate products [10].

The difference between consortia and alliances is that they operate in a single and global in scope respectively [8]. Consortia cover all transport operations and act as independent units in the financial market [9]. Consortia in liner shipping helps efficient utilization of larger vessels because of the vessel sharing arrangement by participating members thus benefiting both larger and smaller carriers. The containerized version of joint services is liner consortia [12]. Consortia can be composed entirely of independent lines, by members of the same conference, or by both conference and non-conference members [18]. Consortia under competition law varies in the various countries; Australia, Canada, Japan, New Zealand and the United States, consortia agreements seem to be entitled to immunity from antitrust law, [18].

\section{E. Global Strategic Alliances}

Alliances are agreements between carriers to cooperate on space and capacity across trade routes, in some cases on a global basis [5]. "Strategic alliances have formed in order to extend economies of scale, scope and network, through strategies such as the integrating of individual service networks, vessel sharing, slot chartering, joint ownership and/or utilization of equipment and terminals and similar endeavors on better harmonization of operations" [11]. Agreement in strategic alliance extends to the use of joint terminals, container station establishment, exchange of information, and among others [5]. Small and medium sized firms face certain challenges when joining alliances as it is a requirement to provide sufficient capacity. Members of the alliance that are not able to meet this requirement will either remain small niche operators or exit the business [5].

In liner shipping before company chooses a trade lane, the company has to decide how big a market share it wishes to obtain [11]. For instance, if the Far East-Europe trade lane is chosen, the shipping line will require very large ships to compete on economies of scale. With regards to the vessel size, O3 has a more advantageous investment in the fleet capacity building compared with the G6 and CKYHE alliances to the fact that they own 20 vessels with capacity from 16,000 to 19,000 TEUs [20]. Hence, forming strategic alliance is the key to making greatest use of those big vessels and benefiting from the economies of scale [20].

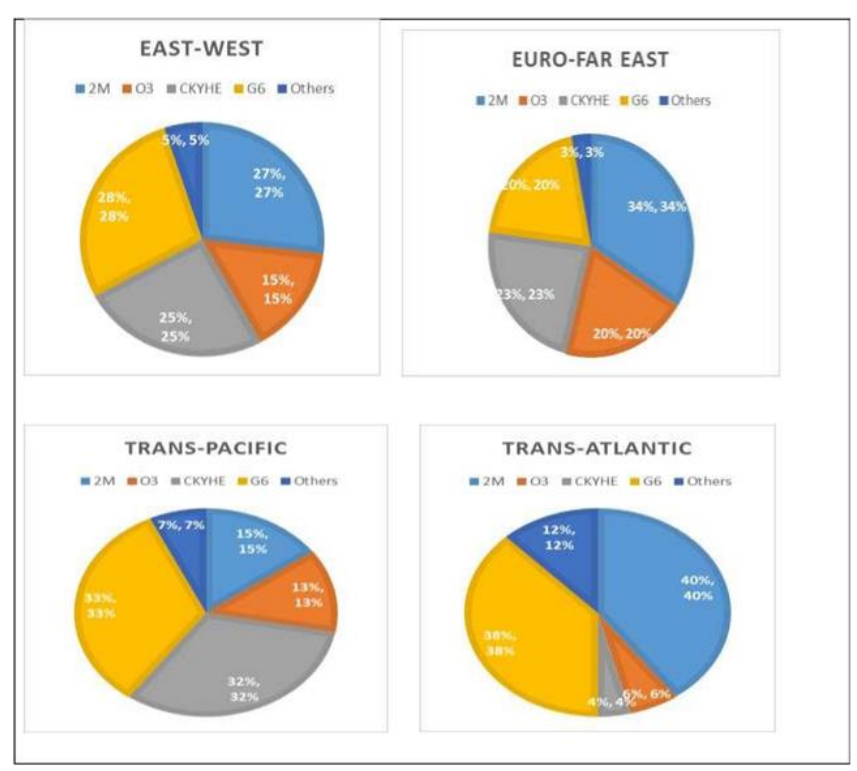

Fig. 1. Market share controlled by 2M, O3, G6 and CKYHE alliances on global trade lanes Source; (Maritime Insight, Volume 2, 2014).

Fig. 1 shows how firms by forming strategic alliances have obtained significant market shares. In the East-West trade lanes G6, 2M and CKYHE alliances dominate with a total market share of $80 \%$. whereas in the Euro-Far East trade route, $2 \mathrm{M}$ alliance is in the lead while G6, CKYHE and O3 alliances equally have around $20 \%$ of the market share. The G6 and CKYHE alliances obviously benefit from a bigger market share of over $30 \%$ each of the trade in Trans-Pacific trade route. The $2 \mathrm{M}$ alliance, however, shows its competitive advantage on the Trans-Atlantic trade route by occupying $40 \%$ of the market share on this route, and only the G6 alliance can compete with it by taking $38 \%$ of the market share. 
Strategic alliances are formed for financial benefits such as; profit maximization, increase in shareholder wealth, capital investment sharing and financial risk reduction, economic advantages as; cost reduction, economies of scale, strategic decision as; entry in new markets, wider geographical scope, increase in purchasing power, marketing benefits such as; satisfy customer requirements better, e.g. higher frequency, flexibility, reliability, network expansion i.e. offering a greater variety of routes and destinations and last but not the least and operational objectives such as increase in frequency of services, vessel planning and coordination on a global scale.

According to [4] liner shipping companies are very relevant in facilitating international trade, not just by enabling the physical transport of the cargoes but also through their involvement in the commercial and marketing aspects of global trade [4]. Examples are the 2M container shipping alliance between Maersk Line and Mediterranean Shipping Co (MSC), the O3 container shipping alliance formed by CMA CGM, China Shipping Container Lines Co. and United Arab Shipping CO, other two are the G6 and CKYHE alliances formed by American President Lines, Hapag Lloyd, Hyundai Merchant Marine, Mitsui, Nippon and OOCL. CKYHE carriers are COSCO, K-line, Yang Ming Line, HANJIN and Evergreen respectively [29]. Carriers pursuit of economies of scale in liner shipping has been their incentive to form strategic alliances, engage in mergers and acquisitions, and their relentless efforts to individually amass huge vessel fleets and increase vessel (plant) capacity by building larger ships [8]. Firms with larger vessels are able to better utilize resources and enjoy economies of scales as they are able to reduce operational cost, expand service coverage and optimize ports of call by forming alliances [29].

Table III and Table IV below show that not only are today's largest carriers predominantly members of global alliances, a significant number of them are leading in investment of new tonnage and especially new super-postpanamax vessels.

TABLE III: LISTS OF LARGE SHIPPING LINES PARTICIPATING IN COOPERATIVE ARRANGEMENT [6]

\begin{tabular}{ccc}
\multicolumn{2}{c}{ COOPERATIVE ARRANGEMENT [6] } \\
\hline Rank & Carrier & Cooperative Arrangement \\
\hline 1 & Maersk-SeaLand & global solo carrier \\
2 & Evergreen & global solo carrier \\
3 & P\&O Nedlloyd & $\begin{array}{c}\text { global strategic alliance member } \\
\text { collection of niches (mainly out of }\end{array}$ \\
4 & Med. Shipping & Europe) \\
5 & Hanjin & global strategic alliance member \\
6 & APL & global strategic alliance member \\
7 & COSCO & global solo, w/web covering major trades \\
8 & NYK & global strategic alliance member \\
9 & MOL & global strategic alliance member \\
& Zim Israel & collection of niches (mainly out of \\
10 & Navigation & Europe) \\
\hline
\end{tabular}

Almost the same carriers appear in the Table below.

Carriers despite being members of the alliance continue to maintain their corporate identities thereby making their partnership reversible and unstable [16]. More recently, a lack of stability in membership of some of the global alliances has been observed, triggering several potential mergers and acquisitions involving their [16] and [2].
TABLE IV: LISTS OF LARGE SHIPPING LINES PARTICIPATING IN COOPERATIVE ARRANGEMENT THAT ORDERED NEW VESSELS [6]

\begin{tabular}{|c|c|c|c|}
\hline 1 & $\begin{array}{c}\text { Maersk } \\
\text { SeaLand }\end{array}$ & global solo & global solo \\
\hline 2 & P\&O Nedlloyd & $\begin{array}{l}\text { Global strategic } \\
\text { alliance member }\end{array}$ & $\begin{array}{l}\text { Global strategic } \\
\text { alliance member }\end{array}$ \\
\hline 3 & Evergreen & global solo & global solo \\
\hline 4 & COSCO & $\begin{array}{l}\text { Global solo, w/web } \\
\text { cover key trades }\end{array}$ & $\begin{array}{c}\text { Global solo, } \\
\text { w/web cover key } \\
\text { trades }\end{array}$ \\
\hline 5 & Hanjin & $\begin{array}{l}\text { global strategic } \\
\text { alliance member }\end{array}$ & $\begin{array}{l}\text { global strategic } \\
\text { alliance member }\end{array}$ \\
\hline 6 & Hapag Lloyd & $\begin{array}{l}\text { global strategic } \\
\text { alliance member }\end{array}$ & $\begin{array}{l}\text { global strategic } \\
\text { alliance member }\end{array}$ \\
\hline 7 & OOCL & $\begin{array}{l}\text { global strategic } \\
\text { alliance member }\end{array}$ & $\begin{array}{l}\text { global strategic } \\
\text { alliance member }\end{array}$ \\
\hline 8 & Yangming & $\begin{array}{l}\text { global solo, w/web } \\
\text { covering key trades }\end{array}$ & $\begin{array}{l}\text { global solo, } \\
\text { w/web covering } \\
\text { key trades }\end{array}$ \\
\hline 9 & MOL & $\begin{array}{l}\text { global strategic } \\
\text { alliance member }\end{array}$ & $\begin{array}{l}\text { global strategic } \\
\text { alliance member }\end{array}$ \\
\hline 10 & APL & $\begin{array}{l}\text { global strategic } \\
\text { alliance member }\end{array}$ & $\begin{array}{l}\text { global strategic } \\
\text { alliance member }\end{array}$ \\
\hline
\end{tabular}

\section{F. Mergers and Acquisition}

Sometimes firms in the liner shipping industry go beyond joining alliances and engage in mergers and acquisition to increase growth [8]. "Mergers and Acquisitions involve the takeover of a competitor's assets and expertise in order to create a new, larger entity" [8]. Since 1995, there have been seven major mergers and over 25 acquisitions. [8] witnessed eminent acquisitions in the liner industry as Hapaq-Lloyd took over CP Ships, CMA CMG bought Delmas from the Bollore Group, and A.P. Moller-Maersk acquired Royal P\&O Nedlloyd [3]. Mergers and acquisitions destabilize shares (however the impact is irrelevant) because they change the composition of the consensus and may produce firms with different objectives, a typical example is when after the Danish carrier, Maersk Lines purchased Sea-Land Service, the combined firm's shares actually dropped in the immediate post-merger period [1]. Mergers and Acquisitions have a role to play in market concentration as they can increase the growth of firms depending on the size of acquisition [5]. There is more risk involved in mergers/acquisitions as a result of the high level of obligations, risk and investment [8]. Carriers have several reasons and incentives that drive them enter into mergers and acquisitions. Some enter for the purpose of economy of scale, market entry or to contain competitors.

\section{Methodology And Data Analysis}

The study adopts both qualitative and quantitative data collection tools as application of either one of them without the other was not possible. General information was obtained from the liner shipping lines and industry worldwide. The qualitative data used for this research was obtained from various research works on the liner shipping lines and industry and data source relied absolutely on secondary source thus from related researches, reports, journals, books, and the google search engine. For this research the quantitative data was more relevant as the main objective of this study is to know market shares ad market concentration of liner shipping lines in Ghana. Volumes of import and export trade of liner shipping lines in the Tema and Takoradi 
Port of Ghana were recorded from the Shipping Review Ghana's Authoritative Quarterly Maritime Journal and the Annual Report of Ghana Shipper's Authority. The Four-Firm Concentration Ratio is used to measure market concentration and define the market structure in this study. Liner shipping lines in Ghana's seaborne trade was the study focus for this research. Their performance in terms of import and export of cargo in the seaborne of the Tema and Takoradi ports of Ghana. Liner shipping lines in the Tema and Takoradi seaborne trade, their individual performances in terms of the volume of their imports and exports trade were obtained individually and used in this study. Ten liner shipping lines were used as the sample size for the study. Between the periods of 2011 and 2015 the total volume trade of the individual liner shipping lines in the seaborne of Ghana were calculated and the top ten in terms of total volume of trade were selected.

\section{A. Market Share Calculation}

The market share calculation in the study was calculated as the total tons of import and export cargo volumes of the individual liner shipping lines in Ghana's Seaborne trade and divided by the grand total import and export cargo volumes of all participants in Ghana's Seaborne liner trade for each year.

Thus, market share of liner firm $\mathrm{A}$ is given as:

$$
A=\frac{\sum(\text { TOTAL TRADE VOLUME OF A })}{\sum(\text { TOTAL TRADE VOLUME OF N })}
$$

where $\mathrm{N}$ is participating members in the liner market.

\section{B. The Market Shares}

\begin{tabular}{cccccc}
\multicolumn{7}{c}{ TABLE V: MARKET SHARES } \\
\hline Lines & 2011 & 2012 & 2013 & 2014 & 2015 \\
\hline Maersk Line & 0.28 & 0.26 & 0.24 & 0.34 & 0.33 \\
Med.Shipp. Co. & 0.15 & 0.19 & 0.15 & 0.13 & 0.18 \\
Pacıfic Intl. Lines & 0.08 & 0.09 & 0.09 & 0.11 & 0.15 \\
Safmarıne & 0.11 & 0.08 & 0.05 & 0.04 & 0.02 \\
Mitsuı O.S.K. Lines & 0.05 & 0.06 & 0.05 & 0.07 & 0.10 \\
Delmas & 0.10 & 0.06 & 0.04 & 0.04 & 0.02 \\
Gold Star Line & 0.04 & 0.06 & 0.04 & 0.07 & 0.07 \\
Cma Cgm & 0.06 & 0.06 & 0.07 & 0.05 & 0.02 \\
Grımaldı Lines & 0.06 & 0.06 & 0.05 & 0.04 & 0.05 \\
Hapag Lloyd & 0.03 & 0.04 & 0.05 & 0.04 & 0.05 \\
\hline
\end{tabular}

Source: Researcher, 2016.

Calculating market concentration using four-firm CR:

$$
C 4=\frac{164002+874979+655856+560113}{5866860}=28 \%+15 \%
$$

TABLE VI: TOP 10 LINER SHIPPING LINES IN GHANA 2011

\begin{tabular}{cccc}
\hline Lines & Tons & Market share & CR4 \\
\hline Maersk Line & 1640002 & $28 \%$ & \\
Med.Shıpp. Co. & 874979 & $15 \%$ & \\
Safmarıne & 655856 & $11 \%$ & \\
Delmas & 560113 & $10 \%$ & \\
Pacific Intl. Lines & 480190 & $8 \%$ & \\
Cma Cgm & 353916 & $6 \%$ & \\
Grımaldı Lines & 323694 & $6 \%$ & \\
Mitsui O.S.K Lines & 287752 & $5 \%$ & \\
Gold Star Line & 261802 & $4 \%$ & \\
Hapag Lloyd & 194559 & $3 \%$ & \\
Others & 233997 & $4 \%$ & \\
Total & 5866860 & $100 \%$ &
\end{tabular}

$$
C 4=\frac{1538588+1110138+553152+499447}{5929318}=26 \%
$$

TABLE VII: TOP 10 LINER SHIPPING LINES IN GHANA 2012

\begin{tabular}{cccc}
\hline Lines & Tons & Market share & CR4 \\
\hline Maersk Line & 1538588 & $26 \%$ & \\
Med.Shipp. Co. & 1110138 & $19 \%$ & \\
Pacific Intl.Lines & 553152 & $9 \%$ & \\
Safmarne & 499447 & $8 \%$ & \\
Mitsui O.S.K Lines & 365047 & $6 \%$ & \\
Cma Cgm & 357509 & $6 \%$ & \\
Delmas & 348710 & $6 \%$ & \\
Gold Star Line & 332038 & $6 \%$ & \\
Grimaldı Lines & 329969 & $6 \%$ & \\
Hapag Lloyd & 217830 & $4 \%$ & \\
Others & 276890 & $5 \%$ & \\
Total & 5929318 & $100 \%$ &
\end{tabular}

Source: (Researcher, 2016.

$$
C 4=\frac{797214+486947+311595+215992}{3286406}=24 \%
$$

TABLE VIII: TOP 10 LINER SHIPPING LINES IN GHANA 2013

\begin{tabular}{cccc}
\hline Lines & Tons & Market share & CR4 \\
\hline Maersk Line & 797214 & $24 \%$ & \\
Med. Shipp. Co. & 486947 & $15 \%$ & \\
Pacific Intl & 311595 & $9 \%$ & \\
Cma Cgm & 215992 & $7 \%$ & \\
Mitsui O.S.K. Lines & 164849 & $5 \%$ & \\
Hapag Lloyd & 155225 & $5 \%$ & \\
Safmarine & 151547 & $5 \%$ & \\
Grimaldi Lines & 150760 & $5 \%$ & \\
Gold Star Line & 126636 & $4 \%$ & \\
Delmas & 120215 & $4 \%$ & \\
Others & 605426 & $18 \%$ & \\
Total & 3286406 & $100 \%$ & $55 \%$ \\
\hline
\end{tabular}

Source: Researcher, 2016

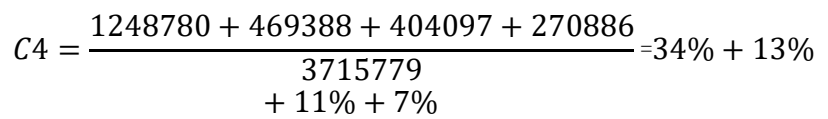

TABLE IX: TOP 10 LINER SHIPPING LINES IN GHANA 2014

\begin{tabular}{cccc}
\hline Lines & Tons & Market share & CR4 \\
\hline Maersk Line & 1248780 & $34 \%$ & \\
Med. Shipp. Co. & 469388 & $13 \%$ & \\
Pacific Intl. & 404097 & $11 \%$ & \\
Gold Star Line & 270886 & $7 \%$ & \\
Mitsui O.S.K. Lines & 248657 & $7 \%$ & \\
Cma Cgm & 180317 & $5 \%$ & \\
Delmas & 165362 & $4 \%$ & \\
Hapag Lloyd & 159391 & $4 \%$ & \\
Grimaldı Lines & 156806 & $4 \%$ & \\
Safmarıne & 130807 & $4 \%$ & \\
Others & 281288 & $8 \%$ & \\
Total & 3715779 & $100 \%$ & \\
\hline
\end{tabular}

Source: Researcher, 2016

TABLE X: TOP 10 LINER SHIPPING LINES IN GHANA 2015

\begin{tabular}{cccc}
\hline Lines & Tons & Market share & CR4 \\
\hline Maersk Line & 1096733 & $33 \%$ & \\
Med. Shipp. Co. & 588908 & $18 \%$ & \\
Pacific Intl. & 493263 & $15 \%$ & \\
Mitsuio.S.K. Lines & 327638 & $10 \%$ & \\
Gold Star Line & 226236 & $7 \%$ & \\
Hapag Lloyd & 159687 & $5 \%$ & \\
Grimaldı Lines & 154799 & $5 \%$ & \\
Cma Cgm & 66980 & $2 \%$ & \\
Delmas & 53381 & $2 \%$ & \\
Safmarıne & 51915 & $2 \%$ & \\
Others & 133139 & $4 \%$ & \\
Total & 3352679 & $100 \%$ & $75 \%$ \\
\hline
\end{tabular}




\section{Data Analysis}

MAERSK LINE and MSC remain in the first and second position respectively throughout the years 2011 to 2015. Computing using the excel spread sheet, Liner concentration level recorded $2011=64 \%, 2012=62 \%, 2013=55 \%, 2014$ $=64 \%$, and $2015=75 \%$ and it is illustrated in the tables .64 , 6.5, 6.6, 6.7 and 6.8 respectively. Almost the same lists of firms are repeated in the years. Also throughout these periods the Liner Concentration level can be classified under Medium Concentration and the Market Structure is considered Monopolistic / Oligopoly.

\section{Oligopoly and Liner Concentration in Ghana's Liner Shipping Trade.}

The study revealed that the liner shipping lines market shares in Ghana is dominated by a few of the many participating firms indicating oligopolistic market structure in the liner shipping market of Ghana. These 'so called' bigger firms constitute low percentage of the total liner firms in the liner shipping trade of Ghana yet they occupy very high market share percentage.

\section{E. Influencing Factors of Market Shares}

There are several factors that that influence the liner shipping lines market shares. Liner shipping lines form cooperative agreement such as global strategic alliances and Consortia to increase firm growth and as a result increase market shares. Mergers and acquisitions have also been another strategy used by these firms to increase growth and market shares. There is also the market demand and market size factors. The larger firms continue to increase their market shares by offering lesser freight rate and value added services and even in some cases have some control or total control over several ports and equipment in the various ports of call.

\section{CONCLUSION}

Based on the forecast results relative smaller firms will decrease in market shares and may have to leave the market. More research must be made on the liner firm industry in Ghana so as to constantly be aware of the market conduct and structure. Larger firms must be 'controlled' and the government authority responsible for liner firms' regulation in Ghana should consider the threat of the concentration level and the oligopolistic nature of the market structure. However, relative smaller firms can still remain in the market when they form cooperative agreements as strategic alliances and consortia. There is also the option of decreasing freight to increase market shares but it must be done very strategically because of the high capital cost involved in liner shipping industry. Consortia and global alliances allow participating firms to have vessel sharing agreement policy. Perhaps cooperative organizations can be complemented with decrease of freight rate so that member firms have lower freight rate charged to their clients giving them competitive advantage over non-member firms. Mergers and Acquisitions must be discouraged as it poses threat to the market conduct and structure.

\section{REFERENCE}

[1] Alphaliner. (2016, April 01). Alphaliner - TOP 100. Retrieved April 06, 2016, from Alphaliner - TOP 100 Operated fleets as per 18 March 2016: http://www.alphaliner.com/top100/.

[2] Benkovskis, K., \& Wörz, J. (2014, February 21). What Drives the Market Share ChangeS? PriCe verSuS non-PriCe FaCtorS. Working PaPer SerieS, p. Working paper 1640.

[3] Clyde, P. S., \& Reitzes, J. D. (1995). The Effectiveness of Collusion Under Antitrust Immunity. Washington, D.C: Federal Trade Commission.

[4] Fusillo, M. (2013). The Stability of Market Shares in Liner Shipping. Review of Industrial Organization, 85-106.

[5] Global Insight. (2005). The Application of Competition Rules to Liner Shipping. European Commission.

[6] Gregory, K. V. (2000). Economies of Scale in International Liner Shipping and Ongoing Industry Consolidation: An Application of Stigler's Survivorship Principle. Blacksburg, Virginia, United States of America.

[7] Haralambides, H. E. (2007). Structure And Operations In The Line Shipping Industry.

[8] Haralambides, P. E. (2011). Determinants Of Price and Price Stability in Liner Shipping. in K. Cullinane, International Handbook of Maritime Economics, (p. 161).

[9] Cheltenham: Edward Elgar.

[10] Hoffmann, J., \& ECLAC, U. (1998). Concentration in liner shipping: its causes and impacts for ports and shipping services in developing regions. Santiago: United Nations.

[11] Kaplow, L. (2013). Market Definition. In R. D. Blair, \& D. D. Sokol, The Oxford Handbook of International Antitrust Economics, Volume 1 (p. Discussion Paper No. 745). Harvard John M. Olin Center for Law, Economics, and Business.

[12] Keithahn, C. F. (1978). The Brewing Industry. Washington: Federal Trade Commission, Bureau of Economics.

[13] Kjeldsen, K. H. (2012). Routing and Scheduling in Liner Shipping. Aarhus: Department of Economics and Business, Aarhus University.

[14] Liu, C. (2009). Maritime Transport Services in the Law of the Sea and the World Trade.

[15] Bern, New York: Peter Lang.

[16] Luo, M., Fan, L., \& Wilson, W. W. (2014). Firm growth and market concentration in liner shipping. Journal of transport economics and policy Vol. 48 pt 1, 171-187.

[17] Maritime Insight, Volume 2. (2014). Strategic Alliance in Container Liner Shipping After P3 Failure. International Centre for Maritime Studies.

[18] Munari, F. (2012). Competition in Liner Shipping. In J. Basedow, U. Magnus, \& R.

[19] Wolfrum, The Hamburg Lectures on Maritime Affairs 2009 \& 2010 (pp. 3-27).

[20] Berlin: Springer Organisation for Economic Co-operation and Development (OECD). (2013). Competition Issues in Liner Shipping. Directorate for Financial fnd Enterprise Affairs Competition Committee.

[21] Panayides, P. M., \& Wiedmer, R. (2011). Strategic alliances in container liner shipping. Research in Transportation Economics volume 32, 25-38.

[22] Premti, A. (2016). Liner Shipping: Is There a Way for More Competition? United Nations.

[23] Schirach-Szmigiel, C. v. (1979). Liner Shipping and General Cargo Transport. Stockholm: Stockholm: Economic research Institute at the Stockholm school of economics [Ekonomiska forskningsinst. vid Handelshögsk.] (EFI), 1979.

[24] Sjostrom, W. (2014). Ocean Shipping Cartels: A Survey. In D. Prokop, The Business of

[25] Transportation (pp. 107-134). Santa Barbara, Califonia: Praeger.

[26] The Free Encyclopedia. (2016, April 09). United States antitrust law. Retrieved from Wikipedia: https://en.wikipedia.org/wiki/United_States_antitrust_law.

[27] Ting, E. (2012). Introduction to Transportation and Navigation.

[28] Tunfors, H. (2001). Liner Conferences. Lunds universitet/Juridiska institutionen 2001.

[29] UNCTAD. (1974). United Nations.

[30] United States. FMC. Bureau of Trade Analysis. (2012). Study of the 2008 repeal of the liner conference exemption from European Union competition law. Washington D.C: Federal Maritime Commission, Bureau of Trade Analysis.

[31] Wernerfelt, B. (1982). The Relation Between Market Share And Profitability. University of Michigan. Graduate School of Business and Administration. Division of Research. 
European Journal of Business and Management Research www.ejbmr.org

[32] World Shipping Council. (2016). Benefits Of Liner Shipping. Retrieved from World Shipping Council: http://www.worldshipping.org/benefits-of-liner-shipping.

[33] World Shipping Council; IHS Global Insight. (2009). Valuation of the liner shipping industry: Economic contribution and liner industry operations. Not identified: Not identified. 